\title{
KARAKTERISTIK MORFOLOGIK DAN MORFOMETRIK SPERMATOZOA AYAM NUNUKAN
}

\author{
F. ARDHANI ${ }^{1}$, I.M.U. RAHARJA ${ }^{1}$, B.M. BOANGMANALU ${ }^{1}$, DAN J. HANDOKO ${ }^{2}$ \\ ${ }^{1} J u r u s a n$ Peternakan Fakultas Pertanian Universitas Mulawarman \\ Jl. Paser Balengkong Kampus Gunung Kelua Samarinda Kalimantan Timur 75129 \\ ${ }^{2}$ Program Studi Peternakan Fakultas Pertanian dan Peternakan UIN Suska Riau \\ E-mail :fikri_ardhani@faperta.unmul.ac.id
}

\begin{abstract}
The fertility of a rooster is not only influenced by motility, viability and DNA integrity of the spermatozoa but also by the morphological integrity of the spermatozoa. The objective of the study was to determine the morphological and morphometric description of spermatozoa in Nunukan rooster, one of Indonesian germplasm. Rooster's semen was collected with dorso-abdominal massage method. The semen was stained with a combination of Eosin and Nigrosin prior to the observation of the morphologic and morphometric parameters. A microscope with 100 times magnification, as many as 100 spermatozoa, was used to evaluate the morphologic aspects. Hereafter, the morphometric aspects were analyzed using the Raster Image program to identify the head dimension, the head length and width, the mid-piece length, the tail length, and the ratio of the head and tail. The spermatozoa of Nunukan rooster showed the average total length of 86.724 $\pm 12.496 \mathrm{~m}$. Furthermore, the head length, the mid-piece length and the tail length are $12.766 \pm 2.307 \mathrm{~m}, 4.220 \pm 1.127 \mathrm{~m}$, and $75.738 \pm$ $9.061 \mathrm{~m}$, respectively, while the head width is $1.391 \pm 0.244 \mathrm{~m}$. On the other hand, the ratio of head length and the tail lenght is 1: 5.9. The morphologic normal percentage is $80.50 \pm 9.40 \%$. In conclusion, the characteristics of spermatozoa of Nunukan rooster due to the aspects of morphologic, morphometric and morphologic normal percentage are within the range of other types of rooster in many previous studies.
\end{abstract}

Keywords : Feed commercial, Golden snail meal, Broiler chicken

\section{PENDAHULUAN}

Ayam nunukan merupakan salah satu plasma nutfah yang dimiliki Indonesia. Melalui Keputusan Menteri Pertanian RI No. 2848/Kpts/LB.430/8/2012, ayam nunukan telah ditetapkan sebagai plasma nutfah Kalimantan Timur yang merupakan aset yang sangat penting karena menjadi bahan mentah dalam program pemuliaan untuk merakit jenisjenis unggul yang sangat penting dalam penyediaan kebutuhan manusia (Nataamijaya, 2010).

Ayam nunukan mempunyai karakteristik dan keunggulan genetik tersendiri yang sangat potensial dilestarikan dan dikembangkan. Karakteristik ayam nunukan antara lain jantan dan betina memiliki bulu coklat sebagai warna dasar, pola warna bulu yang polos, kerlip bulu keemasan, corak bulu polos. Karakteristik dari ayam nunukan adalah lambatnya pertumbuhan bulu pada sayap dan ekornya, yang sangat sedikit/sangat pendek atau bahkan tidak tumbuh sama sekali (Sartika dkk., 2006). Bobot ayam nunukan yang asli dapat mencapai 4 sampai $5 \mathrm{~kg} ; 20-30 \%$ lebih berat dari ayam lokal lainnya, dan produksi telur ayam betina dapat mencapai 182 butir per tahun dengan berat telur 47,5 gram (Wafiatiningsih $d k k$., 2005).

Namun demikian, dalam pemeliharaan konvensional yang tidak memiliki program breeding yang baik, seringkali terjadi jumlah pejantan yang sangat terbatas sehingga proporsinya menjadi tidak berimbang dibandingkan dengan jumlah betinanya. Hal ini pada akhirnya dapat mengakibatkan penurunan produktivitas ayam nunukan secara keseluruhan. Meskipun kontribusi pejantan (sire) dalam produktivitas ternak hanya sebatas pada sperma, namun ketersediaan akan materi regeneratif dari pejantan berupa sperma tersebut sangat dibutuhkan

Mengingat status reproduksi hewan jantan merupakan salah satu faktor penting dalam menunjang keberhasilan penerapan teknologi reproduksi dalam perkembangbiakan ayam nunukan, maka sebagai langkah awal karakteristik spermatozoa perlu diteliti. Karakteristik spermatozoa merupakan suatu hal yang sangat penting untuk mengidentifikasi suatu individu pejantan dan mempunyai nilai di dalam penggunaan kajian reproduksi. Di samping adanya pemeriksaan kualitas semen terhadap konsentrasi, motilitas, viabilitas, kemampuan penetrasi serta kapasitas untuk mengikat oosit; morfologi spermatozoa 
merupakan merupakan salah satu indikator penting dalam penentuan kualitas spermatozoa.

Penelitian ini bertujuan untuk memperoleh informasi kualitas spermatozoa melalui pendiskripsian morfologik dan morfometrik spermatozoa ayam nunukan. Hasil yang diperoleh dapat dijadikan bahan pelengkap utama data potensi reproduksi ayam nunukan yang dapat digunakan untuk memperbaiki dan meningkatkan daya produksi dan reproduksi ayam Nunukan dan dalam melaksanakan program inseminasi buatan (IB) maupun in vitro fertilization (IVF) sebagai sarana program konservasi plasma nutfah Indonesia.

\section{MATERI DAN METODE}

\section{Hewan Penelitian}

Penelitian ini menggunakan 10 ekor ayam nunukan jantan dewasa dengan berat badan 3-4 kg/ekor, umur 30-35 minggu. Ayam ditempatkan pada kandang individual berukuran 50x50x75 $\mathrm{cm}^{3}$ lalu kandang tersebut ditempatkan pada kandang besar dengan ukuran $1 \times 2 \mathrm{~m}^{2}$. Pemberian pakan komersial dilakukan dua kali/hari sebanyak 100-150 $\mathrm{g} /$ hari. Air minum diberikan secara ad libitum. Program vaksinasi, pemberian obat cacing dan vitamin dilakukan secara berkala. Pencahayaan selama 12 jam/hari.

\section{Penampungan Semen}

Penampungan semen dilakukan menggunakan metode masase (pemijatan atau pengurutan) pada bagian dorso abdominal secara halus dari bagian punggung sampai pangkal ekor dan kloaka hingga ayam jantan terangsang yang ditunjukkan dengan ekor terangkat. Pemijatan dilakukan dengan tekanan tertentu sehingga keluar cairan putih dari kloaka dan ditampung menggunakan tabung berskala. Sebelum dilakukan koleksi semen, bagian sekitar kloaka dibersihkan dengan kertas tisu yang telah dibasahi dengan $\mathrm{NaCl}$ fisiologis. Koleksi semen dilakukan dengan interval dua hari sekali pada pukul 09.00-10.00 WITA selama 3 minggu berturut-turut.

\section{Pembuatan Preparat Ulas Semen Segar}

Pembuatan preparat ulas dilakukan dengan menggunakan 3 kaca objek untuk tiap sampelnya. Semen segar dicampurkan dengan larutan $\mathrm{NaCl}$ fisiologis dengan perbandingan 1:4 pada kaca objek pertama. Salah satu sisi ujung kaca objek kedua disinggungkan pada larutan semen dan diulas tipis pada kaca objek ketiga kemudian dikeringudarakan.

Pewarnaan menggunakan kombinasi eosin nigrosin menurut Lukaszewicz et al. (2008); satu bagian $4 \%$ eosin (4 g eosin dilarutkan dalam $96 \mathrm{ml} 2,9 \%$ sodium sitrat dan tiga bagian $8 \%$ nigrosin (8 $\mathrm{g}$ nigrosin dilarutkan dalam $92 \mathrm{ml} \mathrm{2,9 \%}$ sodium sitrat). Sediaan diamati di bawah mikroskop dengan perbesaran lensa objektif 100 kali. Spermatozoa yang hidup tidak akan menyerap warna sedangkan yang mati akan menyerap warna.

\section{Analisis Spermatozoa}

Analisis morfologik spermatozoa dilakukan menggunakan mikroskop cahaya yang dihubungkan dengan camera yang tersambung juga dengan monitor. Penghitungan morfometrik spermatozoa dilakukan dengan cara analisis gambar menggunakan bantuan software Image Raster, satu pixel pada gambar memiliki panjang sebesar 0,489 un untuk perbesaran 10x100.

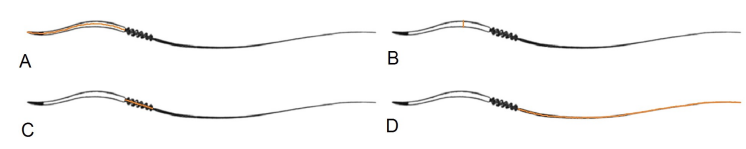

Gambar 1. Aspek penghitungan morfometrik spermatozoa. Keterangan gambar : A) panjang kepala, B) lebar kepala, C) panjang bangian tengah, D) panjang ekor. (Sumber : Jamieson, 2007).

Pengamatan dan pengukuran dilakukan terhadap 100 spermatozoa/sampel. Pengukuran ini meliputi panjang kepala, lebar kepala, panjang bagian tengah dan panjang ekor
(Gambar 1). Selanjutnya dihitung rasio antara panjang kepala dan panjang ekor.

Persentase spermatozoa normal merupakan perbandingan antara jumlah spermatozoa 
normal terhadap jumlah total spermatozoa. Perhitungan dilakukan dengan menghitung 200 spermatozoa pada 10-20 lapang pandang yang berbeda. Persentase spermatozoa normal diperoleh dengan rumus.

Persentase spermatozoa normal $=\frac{\text { jumlah spermatozoa normal }}{\text { jumlah total spermatozoa }} \times 100 \%$

\section{Analisis Data}

Penelitian yang dilakukan merupakan penelitian eksploratif. Data dianalisis secara deskriptif dan konfirmatif dengan variabel yang diukur adalah rata-rata yang didapat dari setiap variabel yang diukur. Hasil yang didapatkan disajikan dengan rata-rata \pm standar deviasi.

\section{HASIL DAN PEMBAHASAN}

Spermatozoa ayam nunukan secara umum memiliki bagian-bagian yang sama dengan spermatozoa ternak mamalia yang lain namun bentuk spermatozoa pada kelompok unggas berbeda. Spermatozoa unggas termasuk ayam nunukan memiliki kepala silindris dengan titik akrosom pada bagian ujungnya, bagian tengah yang pendek dan ekor yang lebih panjang.
Karakteristik morfologik spermatozoa ditunjukan pada Gambar 2. Dalam gambar 2 ini juga ditunjukan reaksi sperma yang mati dan sperma yang hidup, di mana sperma yang telah mati akan menyerap warna sedangkan yang masih hidup tidak menyerap warna eosin (Lukaszewicz et al., 2008).

Spermatozoa ayam Nunukan memiliki kepala sedikit melengkung yang terdiri dari akrosom dan nukleus. Kepala spermatozoa ayam lebih sederhana karena kantung akrosom tidak sampai segmen ekuatorial seperti halnya spermatozoa mamalia (Etches, 1996).

Kepala spermatozoa memiliki panjang $12,766 \pm 2,307 \mu \mathrm{m}$ dan mengandung nukelus atau intisel yang terdiri atas materi genetik. Bagian kepala spermatozoa terdiri atas akrosom dengan panjang $1,911 \pm 0,455 \mu \mathrm{m}$ dan nucleus dengan panjang 10,850 $\pm 1,798 \mu \mathrm{m}$. Akrosom berasal dari badan golgi spermatogonia dan terdiri atas tudung akrosom dan punggung akrosom (Etches, 1996). Akrosom mengandung enzim yang dibutuhkan oleh spermatozoa pada saat fertilisasi, antara lain proakrosin, hialuronidase, zoana lisin esterase dan asam hidrolase (Etches, 1996; Jamieson, 2007).

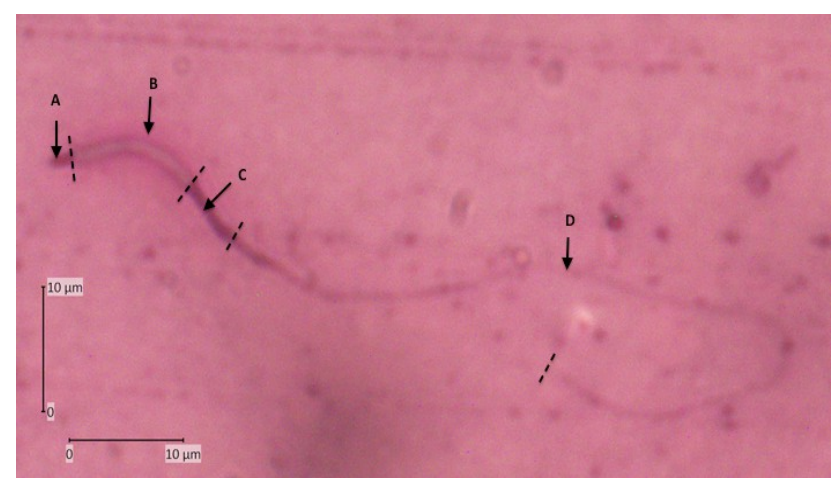

Gambar 2. Karakteristik morfologik spermatozoa ayam Nunukan dengan pengecatan eosin nigrosin. Akrosom (A), Nukleus (B), Bagian Tengah (C), dan Bagian ekor (D)

Bagian tengah spermatozoa memiliki panjang 4,220 $\pm 1,127 \mu \mathrm{m}$. Panjang bagian tengah terkait dengan pasokan energi yang lebih besar melalui produksi ATP dalam mitokondria (Cardullo dan Baltz, 1991). Panjang bagian ekor spermatozoa ayam Nunukan adalah $75,738 \pm 9,061 \mu \mathrm{m}$.
Ekor ini berfungsi sebagai alat gerak spermatozoa. Bagian tengah dan ekor spermatozoa berasal dari mitokondria dan sitoskleton sel yang menyebabkan spermatozoa menjadi motil.

Tabel 1. Morfometrik komponen utama morfologi spermatozoa ayam nunukan 


\begin{tabular}{lc}
\hline & $\mathrm{mm}$ \\
\hline Panjang Kepala & $12,766 \pm 2,307$ \\
- Akrosom & $1,911 \pm 0,455$ \\
- Nukleus & $10,850 \pm 1,798$ \\
Lebar Kepala & $1,391 \pm 0,244$ \\
Bagian Tengah & $4,220 \pm 1,127$ \\
Ekor & $75,738 \pm 9,061$ \\
\hline Total & $94,724 \pm 12,496$ \\
\hline
\end{tabular}

Dalam penelitian ini diketahui bahwa ayam Nunukan memiliki rataan spermatozoa normal sebesar $80,50 \pm 9,40 \%$. Hasil ini sedikit lebih rendah dari studi sebelumnya pada jenis ayam yang dipelihara di Indonesia. Hasil penelitian terhadap persentase spermatozoa normal pada ayam Arab sebesar 85,2\% (Iskandar $d k k$, 2006), ayam kampung 93,8\% (Nurfirman, 2001) dan $84,25 \%$ (Iskandar dkk, 2006), serta ayam pelung $83 \%$ (Iskandar dkk, 2006). Persentase spermatozoa dengan morfologik normal yang di bawah rata-rata jenis ayam lainnya ini dapat disebabkan oleh adanya cekaman panas misalnya suhu di sekitar kandang yang dapat mencapai $33-34^{\circ} \mathrm{C}$ pada siang hari dan dapat pula disebabkan oleh gangguan pada testis. Asupan pakan yang kurang juga dapat mengakibatkan ayam mengalami defisiensi nutrisi dan berdampak pada terganggunya proses spermatogenesis.

Parameter dalam menentukan fertilitas jantan, selain dari motilitas, viabilitas dan keutuhan DNA, dapat diketahui juga dari persentase spermatozoa dengan morfologi normal (Morrell dan Rodriguez-Martinez, 2009, du Plessis dan Soley, 2014), dengan demikian bahwa semakin tingginya persentase abnormal spermatozoa dapat mempengaruhi tingkat fertilitas ayam. Abnormalitas spermatozoa disebabkan oleh beberapa faktor antara lain penyakit, stres panas (manajemen pemeliharaan), proses kriopreservasi, perbedaan bangsa dan strain ayam serta musim. Selain itu tingkat abnormalitas juga bisa disebabkan oleh preservasi pasca koleksi dan pewarnaan.

Rasio kepala dan ekor dari ayam Nunukan adalah 1:5,9; hal ini sesuai dengan Jamieson (2007) yang menyatakan bahwa rasio rasio kepala dan ekor spermatozoa ayam yaitu 1:6. Dimensi sperma terutama difokuskan pada manfaat dari peningkatan ukuran panjang sebagai cara beradaptasi dengan adanya variasi dalam saluran reproduksi betina. Bagian dimensi kepala telah terbukti positif mempengaruhi kesuburan (Samour et al., 1986) dan asumsi umum adalah bahwa ekor sperma akan meningkatkan potensi berenang sperma (Calhim et al, 2011, Humphries et al., 2008). Humphries et al. (2008) menyatakan bahwa meskipun ada sejumlah faktor yang dapat mempengaruhi kecepatan berenang sperma, rasio kepala dan ekor merupakan pengukuran sederhana untuk menilai kecepatan potensial pergerakan spermatozoa. Kleven et al. (2009) menyatakan bahwa kecepatan berenang dan panjang sperma berkembang secara mandiri sebagai hasil dari kompetisi spermatozoa.

\section{KESIMPULAN}

Berdasarkan hasil pengamatan dapat diambil kesimpulan sebagai berikut :

1. Spermatozoa ayam nunukan memiliki panjang total $86,724 \pm 12,496 \mu \mathrm{m}$ dengan panjang kepala $12,766 \pm 2,307 \mu \mathrm{m}$, panjang bagian tengah $4,220 \pm 1,127 \mu \mathrm{m}$, panjang ekor $69,738 \pm 9,061 \mu \mathrm{m}$, sedangkan lebar kepala 1,391 $\pm 0,244 \mu \mathrm{m}$, dan rasio kepala dan ekor adalah 1:5,9.

2. Persentase spermatozoa dengan morfologik normal adalah $80,50 \pm 9,40 \%$.

\section{Saran}

Untuk mengetahui spermatozoa dengan karakteristik morfologik abnormal sebagai salah satu faktor penyebab penurunan nilai fertilitas perlu dilakukan identifikasi jenis dan penyebab abnormalitas morfologik spermatozoa ayam nunukan.

\section{DAFTAR PUSTAKA}

Calhim S., M.C. Double, N. Margraf, T.R. Birkead, and A. Cockburn. 2011. Maintenance of sperm variation in a highly promiscuous wild bird. PLoS One 6 : 28809. 
Cardullo R.A., and J.M. Baltz. 1991. Metabolic Regulation In Mammalian Sperm: Mitochondrial Volume Determines Sperm length and flagellar beat frequency. Cell Motil Cytoskelet.

du Plessis, L. and J.T. Soley. 2014. Light microscopy of emu (Dromaius novaehollandiae) sperm: preparatory technique, morphological features and morphometry. Theriogenology: 81(2) : 203-9.

Etches, R.J. 1996. Reproduction in poultry. 1st Ed. CAB International, Cambridge, UK.

Humphries S, J.P. Evans, and L.W. Simmons. 2008. Sperm competition: linking form to function. BMC Evol Biol, 8 : 319.

Iskandar, S, R. Mardalestari, R. Hernawati, E. Mardiah, dan E. Wahyu. 2006. Pengaruh jenis konsentrasi krioprotektan dan metode thawing pada kualitas semen beku ayam Arab. JITV. 11(1).

Jamieson, B.G.M. 2007. Avian Spermatozoa : Structure and phylogeny. In Jamieson, B. G. M. (Ed.), Reproductive Biology and Phylogeny of Birds: Part A Part A ed. (pp. 349-511) Enfield, USA: Science Publishers.

Kleven O, T.F. Laskemoen, R.J. Robertson, G. Rudolfsen, and J.T. Lifjeld. 2009. Comparative evidence for the swimming speed by sperm competition and female sperm storage duration in passerine birds. Evolution 63 : 2466-73.
Lukaszewicz, E., A. Jersey, A. Partyka, and A. Siudzinska. 2008. Efficacy of evaluation of rooster sperm morphology using different staining methods. Res. Vet. Sci. 85 : 583-588.

Morrell, J.M., and Rodriguez-Martinez, 2009. Biomimetic techniques for improving sperm quality in animal breeding: a review. J The open Andr. 1 : 1-9.

Nataamijaya, A.G. 2010. Pengembangan potensi ayam lokal untuk menunjang peningkatan kesejahteraan petani. J Litbang Pertanian, 29 : 131-138.

Nurfirman. 2001. Efektifitas Medium Beltsville Poultry Semen Extender (BPSE) terhadap Kualitas Semen Cair Ayam Lokal. http://repository.ipb.ac.id.

Samour, J.H., C.A. Smith, H.D. Moore, and J.A. Markham. 1986. Semen collection and spermatozoa characteristics in budgerigars (Melopsittacus undulates). Vet Rec, 118 : 397-9.

Sartika,T., S. Sulandari, M.S.A. Zein dan S. Paryanti. 2006. Ayam nunukan : Karakter Genetik, Fenotipe Dan Pemanfaatannya. Wartazoa. 16(4).

Wafiatiningsih, Sulistyono dan R.A. Saptati. 2005. Performans dan karakteristik ayam nunukan. Pros. Lokakarya Nasional Inovasi Teknologi Pengembangan Ayam Lokal. Puslitbang Peternakan, Badan Litbang Pertanian dan Fakultas Petemakan Univiversitas Diponegoro. 